\title{
Fee for issuing alcoholic beverages for sale in the municipalities of the Kielce Poviat

\author{
Joanna Rogalska
}

Ph.D., Department of Economics and Finance, Faculty of Law and Social Sciences, Jan Kochanowski University, Kielce, Poland.

Email: joanna.rogalska@ujk.edu.pl

\section{Keywords}

Budget, Alcohol, Fee, Income.

\section{Article History}

Received on $6^{\text {th }}$ October 2021

Accepted on $3^{\text {rd }}$ November 2021

Published on $25^{\text {th }}$ November 2021

\section{Cite this article}

Rogalska, J. (2021). Fee for issuing alcoholic beverages for sale in the municipalities of the Kielce poviat. Humanities \& Social Sciences Reviews, 9(6), 22-28. https://doi.org/10.1851 0/hssr.2021.964

Copyright @Author

Publishing License

This work is licensed under a Creative Commons Attribution-Share Alike 4.0 International License

\begin{abstract}
Purpose of the study: The aim of the article is an analysis of revenues for fees for permits for the sale of alcoholic beverages in the own income of municipalities of the Kielce poviat in 2018-2020. It is to enable the answer to be given about the role of the fee for issuing a permit for the sale of alcohol in the incomes of municipalities' own.
\end{abstract}

Methodology: The work was based on the analysis of RB 27S reports on the implementation of the budget income plan of the surveyed municipalities, analysis of internal materials of these units, normative acts and the Local Data Bank

Main findings: The data presented in the paper shows that the share of revenues from fees for the permit to sell alcohol in own income does not exceed $1.7 \%$ and has a downward trend. However, the actual revenue from the levy shows slight fluctuations over the period considered. Moreover, it does not matter whether we are dealing with a rural or an urban-rural commune.

Application of the study: The following study concerns an important aspect of financing the activities of municipalities. Taxes and fees are the most important revenues in budgets. Each decision of the local government authorities has an impact on the level of income. It may lead to a lack of funds for the implementation of own tasks. The year 2021 may be interesting in terms of income from the fee under study due to the possibility of applying a fee exemption or postponing its payment resulting from the provisions of the Act of March 2, 2020 on special solutions related to the prevention, prevention and combating of COVID-19, other infectious diseases and the resulting crises. It is not an easy decision, because such action reduces the revenues to the commune's budget. Due to the fact that for the implementation of tasks for which the funds from the fee were provided, it will have to be financed with other income.

Originality/Novelty of the study: The importance of the financial stability of local government units is an extremely important topic. Topics related to budget planning are essential for the long-term balancing of the demand for funds reported by local governments in relation to the efficiency of funds left at the disposal of local authorities. As a consequence, the subject of the study was the analysis of the dynamics and structure of local authorities' income from the point of view of the selected source of income. The article can inspire further research in the field of local government finance and contribute to other interesting scientific studies. 


\title{
Opłata za wydanie na sprzedaż napojów alkoholowych w dochodach gmin powiatu Kieleckiego
}

\author{
Joanna Rogalska \\ Dr, Katedra Ekonomii i Finansów, Wydział Prawa i Nauk Społecznych, Uniwersytet Jana Kochanowskiego w Kielcach, \\ Poland. \\ E-mail: joanna.rogalska@ujk.edu.pl
}

\author{
Slowa kluczowe \\ budżet, alkohol, opłata, dochody. \\ Historia artykułu \\ Otrzymano 6 października 2021 \\ Przyjęta 3 listopada 2021 \\ Opublikowano 25 listopada 2021
}

\section{Cite this article}

Rogalska, J. (2021). Fee for issuing alcoholic beverages for sale in the municipalities of the

Kielce poviat. Humanities \& Social Sciences

Reviews, 9(6), 22-28. https://doi.org/10.1851

0/hssr.2021.964

Copyright @Author

Publishing License

This work is licensed under a Creative

Commons Attribution-Share Alike 4.0

International License

\section{Wprowadzenie}

\section{Streszczenie}

Cel badawczy: Przedmiotem opracowania jest analiza wpływów za opłaty za zezwolenia na sprzedaż napojów alkoholowych w dochodach własnych gmin powiatu kieleckiego w latach 2018-2020. Ma ona umożliwić udzielenie odpowiedzi jaka jest rola opłaty za wydawanie zezwolenia na sprzedaż alkoholu w dochodach własnych gmin.

Metodologia: Praca powstała na bazie analizy sprawozdań RB 27S z wykonania planu dochodów budżetowych badanych gmin, analizy materiałów wewnętrznych tych jednostek, aktów normatywnych $\mathrm{z}$ dziedziny finansów publicznych oraz Banku Danych Lokalnych.

Główne wnioski: Dane zaprezentowane w pracy pokazuje, że udział wpływów z opłat na zezwolenie na sprzedaż alkoholu w dochodach własnych nie przekracza $1,7 \%$ oraz ma tendencje malejącą. Jednak faktyczne wpływy z opłaty wskazują na niewielkie wahnięcia $\mathrm{w}$ badanym okresie. Ponadto na wysokość wpływów nie ma znaczenia fakt czy mamy do czynienia z gminą wiejską czy miejsko-wiejską.

Zastosowanie badania: Poniższe opracowanie dotyczy ważnego aspektu jakim jest finansowanie działalności gmin. Podatki i opłaty stanowią najważniejsze dochody w budżetach. Każda decyzja władz samorządowych, która ma wpływ na poziom dochodów może spowodować brak środków na realizację zadań własnych. Ciekawym pod względem dochodów z badanej opłaty może być rok 2021 z uwagi na możliwość zastosowania zwolnienia z opłaty lub przesunięcia jej wpłaty wynikającym z przepisów ustawy z 2 marca 2020 r. o szczególnych rozwiązaniach związanych $\mathrm{z}$ zapobieganiem, przeciwdziałaniem i zwalczaniem COVID-19, innych chorób zakaźnych oraz wywołanych nimi sytuacji kryzysowych. Nie jest to łatwa decyzja, bo takie działanie uszczupla wpływy do budżetu gminy. Powodując, że na realizację zadań na które przewidziane były środki z opłaty trzeba będzie sfinansować innymi dochodami.

Oryginalność badań: Znaczenie stabilności finansów jednostek samorządu terytorialnego jest tematem niezwykle ważnym. Tematyka, która dotyczy zagadnień związanych $\mathrm{z}$ planowaniem budżetowym, jest niezbędna dla długoterminowego równoważenia zapotrzebowania na fundusze zgłaszanego przez samorząd terytorialny w stosunku do wydajności pozostawionych do dyspozycji władz lokalnych środków. W konsekwencji przedmiotem opracowania stała się analiza dynamiki i struktury dochodów władz samorządowych z punktu widzenia wybranego źródła dochodów. Artykuł może inspirować do dalszych badań w sferze finansów samorządowych oraz przyczynić się do powstawania innych ciekawych opracowań naukowych.

Głównym celem funkcjonowania gminy jest zapewnienie jak najlepszych warunków dla rozwoju społeczności go zamieszkującej. Jego realizacja wymaga jednak zapewnienia stałego dopływu środków niezbędnych do finansowania właściwego poziomu dóbr i usług publicznych. Rozumiana w ten sposób zdolność do pełnienia swoich funkcji w sposób nieprzerwany i efektywny określana jest mianem stabilności finansowej. Kolejnym ważnym atrybutem gmin (i pozostałych jednostek samorządu terytorialnego) jest ich samodzielność. Samodzielność gmin przejawia się jako możliwość decydowania o swoich sprawach w ramach obowiązującego prawa, niezależnie od innych podmiotów. Innymi słowy to przyznanie organom lokalnym prawa do decydowania o wysokości i strukturze dochodów, wydatków, przychodów i rozchodów oraz do tworzenia i wykonywania budżetu danej jednostki (Rogalska, 2016, s. 217-234).

Z punktu widzenia samodzielności gminy ważnym jest tu podział na dochody własne, dotacje i subwencje (Konstytucja, 1997 , art. 167). Dochody własne to wszystkie dochody przyznane samorządom na czas nieokreślony w drodze ustawy oraz te, pochodzące z majątku jednostki. Zalicza się do nich: (Misiąg, 2004, s. 34) 
- podatki przyznane gminom jako dochody własne,

- udziały we wpływach z podatków dochodowych odpowiednio: od osób fizycznych i od osób prawnych,

- opłaty przyznane gminom jako ich dochody własne,

- dochody z majątku gmin,

- inne dochody należne gminom na podstawie odrębnych przepisów.

W dalszej części pracy przedstawione zostanie miejsce w dochodach własnych wpływów z konkretnej opłaty - opłaty za zezwolenia na sprzedaż alkoholu.

\section{Przegląd literatury}

Rozważania dotyczące opłaty należy zacząć od ogólnego pojęcia, czyli definicji opłaty. Okazuje się jednak, że pomimo licznych ustaw regulujących zasady ich naliczania i poboru żadna samego pojęcia nie określa. Warto tu jednak zaznaczyć, że termin opłata jest używany równolegle $z$ terminem podatek, więc można przyjąć, że może mieć on podobne właściwości. Pojęcie podatku zostało zdefiniowane w ustawie o Ordynacji podatkowej, zgodnie z którą podatek to ,publicznoprawne, nieodpłatne, przymusowe oraz bezzwrotne świadczenie pieniężne na rzecz Skarbu Państwa, województwa, powiatu lub gminy, wynikające z ustawy podatkowej” (Ustawa. 1997, art. 6). Cechy, które odróżniają podatek od opłaty, to ekwiwalentność i zindywidualizowanie. Opłata jest zatem „indywidualną zapłatą za zindywidualizowane świadczenie" (Gomułowicz i in. 2008, s. 137) i jest ona pobierana w związku z określonymi czynnościami organów samorządowych. Osoba lub podmiot, który ponosi opłatę uzyskuje własną, odrębną korzyść. Może ona polegać na otrzymaniu zaświadczenia, uzyskaniu zezwolenia na sprzedaż alkoholu czy zgody na przesunięcie terminu zapłaty podatku. Jednakże, należy tu podkreślić, że $w$ praktyce cecha ekwiwalentności ulega zmarginalizowaniu, powodując zatarcie wyraźnej granicy między podatkiem a opłatą (Hanusz i in. 2006, s. 158). Brak znamion ekwiwalentności nadaje tym opłatom charakter quasi-podatków.

Wszystkie kategorie opłat ustalane są na szczeblu centralnym mocą ustawy. Oznacza to, że władze gminy (jak i innych samorządów) nie mogą ustalać opłat nieprzewidzianych prawem.

Opłata za wydanie zezwolenia na sprzedaż alkoholu regulowana jest przepisami ustawy o wychowaniu w trzeźwości i przeciwdziałaniu alkoholizmowi (Ustawa, 1982). Jest to opłata, nieco różniąca się od innych z uwagi na pewne odstępstwo od zasady jedności materialnej budżetu. Zgodnie z wspomnianą zasadą, wszystkie dochody trafiające do budżetu mają przeznaczenie ogólne, czyli nie służą finansowaniu wskazanego zadania (Owsiak, 2005, s. 24). W przypadku opłaty za wydanie zezwolenia na sprzedaż alkoholu ustawa wiąże wpływy z tego podatku z konkretnym wydatkiem. Dochody gromadzone za jej pomocą mogą być wykorzystane wyłącznie na realizację gminnych programów profilaktyki i rozwiązywania problemów alkoholowych oraz Gminnych Programów, wynikających z ustawy o przeciwdziałaniu narkomanii, z uwzględnieniem przepisów o wspieraniu rodziny i systemie pieczy zastępczej (Nawrolska, 2017, s. 296). Kolejną cechą różniącą opłatę za zezwolenie na sprzedaż napojów alkoholowych od innych opłat jest jej wysokość oraz sposób ustalania.

Opłata za wydanie zezwolenia na sprzedaż alkoholu obejmuje sprzedaż detaliczną i hurtową. Dochody z opłaty w części detalicznej zasilają budżety gmin, zaś części hurtowej budżety wojewódzkie. Ma ona pewne cechy skarbowej, gdyż wiąże się z uzyskaniem zezwolenia na podstawie pisemnego wniosku przedsiębiorcy. Uiszczana jest jednak niezależnie od niej, a więc przedsiębiorca reguluje dwie wspomniane opłaty. Uzależniona jest od wartości sprzedaży różnych kategorii napojów alkoholowych skatalogowanych w zależności od stopnia zawartości alkoholu (Sekuła, 2010 s. 279). Z uwagi na to, że opracowanie dotyczy gmin w dalszej części zostaną przybliżona opłata za zezwolenie na sprzedaż alkoholu w części detalicznej.

Opłata w części detalicznej złożona jest z dwóch części - opłaty za wydanie zezwolenia oraz corocznej składki, której wielkość uwarunkowana jest ilością sprzedanego alkoholu. Pierwszą opłatą ponoszoną przez przedsiębiorców jest opłata za wydanie zezwolenia. Opłata za jego wydanie uzależniona jest od rodzajów trunków. Wyróżnia się tu pozwolenie na sprzedaż (Ustawa, 1982, art. 1111):

- napojów zawierających do 4,5\% alkoholu oraz piwa -525 zł

- napojów zawierających powyżej 4,5\% do $18 \%$ alkoholu (z wyjątkiem piwa) - 525 zł

- napojów zawierających powyżej $18 \%$ alkoholu - 2100 zł

Należy tu zaznaczyć, że sprzedaż w jednym miejscu piwa, wina i wódki wymaga uzyskania wszystkich trzech zezwoleń i wówczas opłata wyniesie $3150 \mathrm{zł}$.

Jednak opłata za wydanie zezwolenia to nie jedyny wydatek związany ze sprzedażą alkoholu. Koniecznym jest to również odprowadzanie corocznej składki za sprzedaż alkoholu.

Jej wysokość ustala się na podstawie oświadczenia o wielkości sprzedaży alkoholu w poprzednim roku, które składa się do 31 stycznia. Jeżeli wartość sprzedaży napojów alkoholowych w roku poprzednim przekroczyła: (Ustawa. 1982, art. $\left.\underline{11^{1}}\right)$ 
- 37500 zł dla napojów alkoholowych o zawartości do 4,5\% alkoholu oraz piwa - wnosi w wysokości 1,4\% ogólnej wartości sprzedaży tych napojów w roku poprzednim;

- 37500 zł dla napojów alkoholowych o zawartości od 4,5\% do $18 \%$ alkoholu (z wyjątkiem piwa) - wnosi w wysokości 1,4\% ogólnej wartości sprzedaży tych napojów w roku poprzednim;

- 77000 zł dla napojów alkoholowych o zawartości powyżej 18\% alkoholu - wnosi w wysokości 2,7\% ogólnej wartości sprzedaży tych napojów w roku poprzednim.

Jeżeli wartość obrotu nie przekroczyła wskazanych kwot, wówczas konieczne jest wniesienie opłat takich, jak w przypadku wydania zezwolenia na sprzedaż alkoholu.

Wskazana składka płatna w trzech równych ratach w terminach do 31 stycznia, 31 maja i 30 września danego roku kalendarzowego lub jednorazowo $w$ terminie do 31 stycznia danego roku kalendarzowego.

Ponadto liczba zezwoleń na sprzedaż alkoholu podlega pewnym ograniczeniom. Rada gminy ustala maksymalną liczbę zezwoleń na sprzedaż napojów alkoholowych na terenie gminy, odrębnie dla: (Ustawa, 1982, art. 12)

- poszczególnych rodzajów napojów alkoholowych,

- zezwoleń na sprzedaż napojów alkoholowych przeznaczonych do spożycia w miejscu sprzedaży;

- zezwoleń na sprzedaż napojów alkoholowych przeznaczonych do spożycia poza miejscem sprzedaży.

Jak wspomniano wcześniej wpływy z opłaty za wydawanie zezwoleń na sprzedaż napojów alkoholowych zasilają budżet konkretnych wydatków. Środki te mogą być przeznaczone na realizację : (Ustawa, 1982, art. 18²)

- gminnych programów profilaktyki i rozwiązywania problemów alkoholowych oraz Gminnych Programów opracowanych na podstawie ustawy o przeciwdziałaniu narkomanii (Ustawa, 2005);

- zadań realizowanych przez placówkę wsparcia dziennego, o której mowa w przepisach o wspieraniu rodziny i systemie pieczy zastępczej, w ramach gminnego programu profilaktyki i rozwiązywania problemów alkoholowych oraz Gminnych Programów opracowanych na podstawie ustawy o przeciwdziałaniu narkomanii (Ustawa, 2005)

Wysoka opłata za zezwolenie oraz ograniczona liczba zezwoleń stanowi jeden z instrumentów ograniczenia liczby podmiotów, a pośrednio ograniczenia dostępności alkoholu w kraju.

\section{Metodologia}

Celem przedstawionych badań jest analiza wpływów za opłaty za zezwolenia na sprzedaż napojów alkoholowych w dochodach własnych gmin powiatu kieleckiego w latach 2018-2020. Ma ona umożliwić udzielenie odpowiedzi na pytanie o zmiany w znaczeniu opłaty za wydawanie zezwolenia na sprzedaż alkoholu w dochodach własnych gmin.

Obszar badawczy obejmuje 19 gmin, z czego 8 o charakterze miejsko-wiejskim i 11 gmin o charakterze wiejskim.

Publikacja została przygotowana na podstawie analizy sprawozdań RB 27S z wykonania planu dochodów budżetowych badanych gmin, analizy materiałów wewnętrznych tych jednostek, aktów normatywnych $\mathrm{z}$ dziedziny finansów publicznych oraz Banku Danych Lokalnych.

\section{Wyniki}

W tabeli 1 zaprezentowane zostały wpływy do budżetów gminnych z opłat na zezwolenie na sprzedaż alkoholu.

Tabela 1: Wpływy z opłat na zezwolenie na sprzedaż alkoholu w gminach powiatu Kieleckiego w latach 2018-2020

\begin{tabular}{ccccc}
\hline \multirow{2}{*}{ Gminy powiatu kieleckiego } & \multicolumn{2}{c}{ oplata za zezwolenie na sprzedaż napojów alkoholowych } \\
\cline { 3 - 5 } & & \multicolumn{3}{c}{ w tys. zl } \\
\cline { 3 - 5 } & wiejska & 109,16 & $\mathbf{2 0 1 9}$ & $\mathbf{2 0 2 0}$ \\
\hline Bieliny & miejsko-wiejska & 162,22 & 105,39 & 115,36 \\
\hline Bodzentyn & miejsko-wiejska & 246,15 & 168,66 & 184,68 \\
\hline Chęciny & mis & 250,54 & 239,51 \\
\hline Chmielnik & miejsko-wiejska & 217,64 & 220,93 & 224,84 \\
\hline Daleszyce & miejsko-wiejska & 201,67 & 207,40 & 221,40 \\
\hline Górno & wiejska & 183,35 & 201,06 & 212,69 \\
\hline Łagów & miejsko-wiejska & 108,01 & 113,28 & 109,99 \\
\hline Łopuszno & wiejska & 104,46 & 120,86 & 127,06 \\
\hline Masłów & wiejska & 140,68 & 136,48 & 142,90 \\
\hline Miedziana Góra & wiejska & 177,32 & 191,58 & 198,45 \\
\hline \multicolumn{2}{c}{ Mniów } & wiejska & 118,20 & 122,31 \\
\hline
\end{tabular}




\begin{tabular}{ccccc}
\hline Morawica & miejsko-wiejska & 251,40 & 264,23 & 236,93 \\
\hline Nowa Słupia & miejsko-wiejska & 170,29 & 181,65 & 180,62 \\
\hline Nowiny & wiejska & 227,70 & 239,13 & 294,98 \\
\hline Piekoszów & wiejska & 68,87 & 75,94 & 75,83 \\
\hline Pierzchnica & miejsko-wiejska & 84,10 & 84,27 & 86,01 \\
\hline Raków & wiejska & 117,81 & 175,80 & 111,15 \\
\hline Strawczyn & wiejska & 150,33 & 145,35 & 161,68 \\
\hline Zagnańsk & wiejska & 182,71 & 201,93 & 205,07 \\
\hline
\end{tabular}

Źródło: Opracowanie własne.

Analizując zaprezentowane dane można zauważyć, że wpływy z przedmiotowej opłaty są dość stabilnym źródłem dochodu w badanym okresie. Największe wahania obserwowane są w gminie Raków (wysokie wpływy z 2019 r. na poziomie 175 tys. zł, gdzie w pozostałym okresie wynoszą 117 tys. i 111 tys. zł). natomiast najmniej zasobne we wpływy są gminy Piekoszów i Pierzchnica, w których wpływy z badanej opłaty nie przekroczył 86 tys. zł).

Tabela 2: Udział wpływów z opłat na zezwolenie na sprzedaż alkoholu w dochodach własnych w dochodach podatkowych oraz opłatach w gminach powiatu kieleckiego w latach 2018-2020

\begin{tabular}{|c|c|c|c|c|c|c|c|c|c|}
\hline & \multicolumn{3}{|c|}{ dochody wlasne } & \multicolumn{3}{|c|}{ dochody podatkowe* } & \multicolumn{3}{|c|}{ opłaty** } \\
\hline & \multicolumn{9}{|c|}{$\%$} \\
\hline & 2018 & 2019 & 2020 & 2018 & 2019 & 2020 & 2018 & 2019 & 2020 \\
\hline Bieliny & 1,10 & 1,02 & 0,66 & 6,45 & 5,61 & 6,26 & 24,11 & 24,14 & 10,57 \\
\hline Bodzentyn & 1,29 & 0,95 & 0,91 & 3,79 & 3,43 & 3,49 & 18,58 & 15,59 & 13,12 \\
\hline Chęciny & 1,01 & 0,89 & 0,7 & 3,53 & 3,38 & 2,73 & 11,13 & 9,69 & 8,13 \\
\hline Chmielnik & 1,39 & 1,18 & 0,95 & 3,83 & 3,80 & 3,64 & 13,36 & 11,84 & 9,48 \\
\hline Daleszyce & 0,80 & 0,72 & 0,68 & 1,81 & 1,63 & 1,72 & 21,64 & 22,70 & 13,47 \\
\hline Górno & 1,21 & 0,84 & 0,75 & 4,64 & 4,68 & 4,39 & 15,66 & 15,41 & 8,81 \\
\hline Łagów & 0,96 & 0,56 & 0,72 & 3,39 & 3,26 & 2,86 & 3,79 & 3,35 & 3,93 \\
\hline Łopuszno & 1,10 & 0,94 & 0,85 & 3,59 & 4,22 & 4,39 & 18,36 & 13,67 & 10,51 \\
\hline Masłów & 0,65 & 0,60 & 0,53 & 2,01 & 2,02 & 2,01 & 11,74 & 8,20 & 6,67 \\
\hline Miedziana Góra & 1,00 & 1,04 & 0,74 & 4,33 & 4,44 & 4,30 & 11,14 & 12,76 & 9,55 \\
\hline Mniów & 1,67 & 1,23 & 0,88 & 5,71 & 5,72 & 5,10 & 23,14 & 23,23 & 8,75 \\
\hline Morawica & 0,66 & 0,53 & 0,44 & 2,07 & 2,11 & 1,74 & 8,69 & 8,38 & 5,39 \\
\hline Nowa Słupia & 1,57 & 0,99 & 0,85 & 9,84 & 8,26 & 7,44 & 20,93 & 19,73 & 13,60 \\
\hline Nowiny & 0,85 & 0,64 & 0,77 & 2,40 & 2,43 & 2,94 & 6,28 & 5,29 & 5,77 \\
\hline Piekoszów & 1,33 & 1,20 & 0,77 & 3,42 & 3,68 & 3,46 & 18,56 & 18,22 & 11,43 \\
\hline Pierzchnica & 1,24 & 0,99 & 0,53 & 4,49 & 4,16 & 4,04 & 19,75 & 19,38 & 13,75 \\
\hline Raków & 0,30 & 0,43 & 0,27 & 0,57 & 0,90 & 0,60 & 2,58 & 3,65 & 2,18 \\
\hline Strawczyn & 1,08 & 0,76 & 0,77 & 2,68 & 2,41 & 2,66 & 22,41 & 20,85 & 15,74 \\
\hline Zagnańsk & 0,88 & 0,90 & 0,71 & 3,12 & 3,73 & 3,38 & 26,03 & 28,03 & 13,65 \\
\hline \multicolumn{10}{|c|}{$\begin{array}{l}\text { * - podatek rolny, podatek od nieruchomości, podatek leśny, podatek od środków transportowych, podatek od } \\
\text { działalności gospodarczej osób fizycznych opłacany w formie karty podatkowe, podatek od spadków i darowizn, } \\
\text { podatek od czynności cywilnoprawnych }\end{array}$} \\
\hline ** - opłata skarb & ta eks & tacyj & prate & ZWOI & Spir & lkohol & płata re & 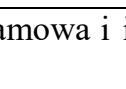 & e opłaty \\
\hline
\end{tabular}

Źródło: Opracowanie własne.

Analizując dane zaprezentowane w tabeli 2 można zauważyć, że udział wpływów z opłat na zezwolenie na sprzedaż alkoholu w dochodach własnych nie przekracza 1,7\% oraz ma tendencje malejącą. A ponieważ $\mathrm{z}$ danych z tabeli 1 nie wynika tak duża obniżka z wpływów z badanej opłaty, oznacza to, że w dochodach własnych rosną wpływy z innych źródeł. Można tu wskazać chociażby podatek od nieruchomości czy wpływy z innych opłat pobieranych na podstawie odrębnych ustaw.

W odniesieniu do udziału wpływów z opłat na zezwolenie na sprzedaż alkoholu na tle dochodów podatkowych można zauważyć, na dość duży poziom zróżnicowania. W badanym okresie udział ten wacha się od $0,6 \%$ do $9 \%$. Wysoki udział gminy Nowa Słupia ciężko wytłumaczyć patrząc na wysokość faktycznych wpływów (tabela 1) 


\section{Dyskusja}

Zezwolenie na sprzedaż napojów alkoholowych jest formą reglamentacji detalicznej sprzedaży napojów alkoholowych. Ustawodawca nie wprowadza tu ograniczenia co do ilości zezwoleń na sprzedaż napojów alkoholowych na terenach gmin, których można udzielić jednemu przedsiębiorcy, ani nie umocowuje żadnego organu do wprowadzenia takiego ograniczenia. Ustawodawca przyznał jedynie radom gmin kompetencję do ustalenia, w drodze uchwały liczby zezwoleń na sprzedaż napojów alkoholowych na terenie gminy.

Analizując zaprezentowane dane można zauważyć, że status gminy nie ma wpływu na wysokość wpływów z opłat. Tabela 1 pokazuje, że dochody z badanej opłaty są niezależne od tego czy mamy do czynienia z gminą wiejską czy gmina miejsko wiejską.

Zaobserwować, można tendencje malejącą udziału opłat za zezwolenia na sprzedaż alkoholu w dochodach własnych, na rzecz innych dochodów.

Analizując wpływy z poszczególnych podatków w porównaniu z wpływami z opłat za zezwolenia na sprzedaż alkoholu można zauważyć, że $\mathrm{w}$ badanych gminach $\mathrm{w}$ nieco niższa od wpływów z podatku rolnego czy leśnego. Jednakże wpływy z tej opłaty znacznie przewyższają dochody z podatku od spadków i darowizn (do 70 tys. zł) czy opłaty skarbowej (do 60 tys. zt).

Natomiast udział wpływów z opłat na zezwolenie na sprzedaż alkoholu w innych opłatach z działu 75618 jest dość zróżnicowany. Związane jest to między innymi z wpływami z opłaty eksploatacyjnej. Na badanym obszarze tylko pięć gmin nie ma wpływów z opłaty eksploatacyjnej: Bieliny, Bodzentyn, Raków, Strawczyn, Zagnańsk. W pozostałych dochody z tej opłaty są różne. Największe osiągają: Nowiny (ponad $4 \mathrm{mln}$ zł), Piekoszów (powyżej 3 mln zł), Łagów (powyżej $2 \mathrm{mln}$ zł), Chęciny i Morawica (powyżej $1 \mathrm{mln}$ zł), zaś w pozostałych dochody te są z przedziału od 11 do 700 tys. zł. Stąd w gminach, gdzie dochody z opłaty eksploatacyjne są niskie lub sama opłata nie występuje charakteryzują się wyższym udziałem dochodów z opłat za zezwolenia na sprzedaż alkoholu. Ciekawym przypadkiem jest gmina Raków, w której udział badanej opłaty w każdym ułożeniu jest dość niski, zaś faktyczne wpływy nie odstają od innych gmin. Jest to efektem tego, że w dochodach własnych bardzo duży udział mają wpływy z usług (w 2018 r. - 1,4 mln zł, 2019 r. - 1,8 mln zł oraz 2020 r. - 1 mln zł, jednak w 2020 roku wpływ na zmniejszone dochody z usług miała też pandemia Covid-19). W pozostałych badanych gminach dochody z usług kształtowały się w przedziale od 18 do 600 tys zł.

\section{Ograniczenia i kierunki badań}

Rok 2021 może okazać się rokiem ze znacznym obniżeniem lub nawet brakiem wpływów z tytułu opłaty za zezwolenie na sprzedaż alkoholu. Związane jest to $\mathrm{z}$ możliwością zwolnienia $\mathrm{z}$ opłaty lub przedłużenia terminu na jej wniesienie, która wynika z zastosowania przepisów ustawy Covid-19 z marca 2020 r. (Ustawa, 2020, art. 31zzca). Na ten krok decyduje się coraz więcej gmin. Nie jest to łatwa decyzja, bo takie działanie uszczupla wpływy do budżetu gminy. Powodując, że na realizację zadań, na które przewidziane były środki z opłaty trzeba będzie sfinansować innymi dochodami. Jednak z powodu zamknięcia przez pandemię branża gastronomiczna znalazła się na skraju wytrzymałości finansowej, więc każda ulga jest dla przedsiębiorców dużą pomocą.

Ciekawym aspektem jest również możliwość wydatkowania środków pochodzących z opłaty za zezwolenia na sprzedaż napojów alkoholowych na cele inne niż wskazane w ustawie. Na mocy wspomnianej wcześniej ustawy Covid-19 (Ustawa, 2020, art. 15qc) do dnia 31 grudnia 2020 r. wójt (burmistrz, prezydent miasta) może wykorzystać dochody z opłat za zezwolenia na sprzedaż alkoholu na działania związane z przeciwdziałaniem COVID-19. Stworzyło to gminom możliwość do alternatywnego przeznaczenia środków pochodzących z opłat na szeroko rozumiane wydatki z dotyczące przeciwdziałaniu Covid-19. Ze środków zostały zakupione np. laptopy do zdalnego nauczania, zakup środków ochrony osobistej itp. Jednak warto tu podkreślić, że działanie takie było możliwe jedynie do końca 2020 r.

\section{Bibliografia}

1. Gomułowicz, A., Małecki, J. (2008). Podatki i prawo podatkowe., Warszawa: LexisNexis.

2. Hanusz. A., Niezgoda. A., Czerski. P. (2006). Dochody budżetu gminy, Warszawa: Oficyna Wolters Kluwer Business.

3. Konstytucja Rzeczypospolitej Polskiej z dnia 2 kwietnia 1997 r., Dz.U. 1997 Nr 78, poz. 483.

4. Misiąg. W. (2004), Budżet gminy dla praktyków, Warszawa: MUNICIPIUM S.A.

5. Nawrolska I. (2017). Opłata za wydanie zezwolenia na sprzedaż alkoholu jako źródło finansowania profilaktyki alkoholizmu. Prace Naukowe Uniwersytetu Ekonomicznego we Wrocławiu, Relacje fiskalne państwo samorząd terytorialny, 485, s. 291-307. https://doi.org/10.15611/pn.2017.485.23

6. Owsiak S. (2005), Finanse publiczne. Teoria i praktyka, Warszawa: Wydawnictwo Naukowe PWN.

7. Rogalska J. (2016) System podatkowy jako narzędzie rozwoju lokalnego. W: E. Łyżwa (red.), Państwo polskie wobec współczesnej rzeczywistości gospodarczej - wyzwania ekonomiczne, społeczne, etyczne, (s.217-234). Kielce: Uniwersytet Jana Kochanowskiego w Kielcach.

8. Sekuła A. (2010). Dochody gmin z tytułu opłat. Prace Naukowe Uniwersytetu Ekonomicznego we Wrocławiu, Dylematy rozwoju lokalnego i regionalnego na początku XXI wieku, 101, s. 272-280. 
9. Ustawa 2.03.2020 r. o szczególnych rozwiązaniach związanych z zapobieganiem, przeciwdziałaniem i zwalczaniem COVID-19, innych chorób zakaźnych oraz wywołanych nimi sytuacji kryzysowych, tekst jednolity: Dz.U. 2020 poz. 1842.

10. Ustawa z 26.10.1982 r. o wychowaniu w trzeźwości i przeciwdziałaniu alkoholizmowi, tekst jednolity: Dz.U. 2021 poz. 1119.

11. Ustawa 29.07.2005 r. o przeciwdziałaniu narkomanii, tekst jednolity: Dz.U. 2020 poz. 2050.

12. Ustawa 29.08.1997 r. Ordynacja podatkowa, tekst jednolity: Dz.U. 2021 poz. 1540. 